\title{
Potensi Pakan Fermentasi Anaerob Menggunakan Bahan Pakan Lokal untuk Ternak Itik
}

\section{(Potential of Anaerobic Fermentation Using Local Feed Ingredient for Ducks)}

\author{
Allaily ${ }^{1}$, Miswar ${ }^{2}$, Rianah $\mathrm{S}^{2}$, Usman $\mathrm{Y}^{3}$, Zulfan ${ }^{1}$, Yaman MA \\ ${ }^{1}$ Laboratorium Ilmu dan Teknologi Produksi Unggas, Program Studi Peternakan, Fakultas Pertanian \\ ${ }^{2}$ Program Studi Peternakan, Fakultas Pertanian \\ ${ }^{3}$ Laboratorium Ilmu Nutrisi Ternak, Program Studi Peternakan, Fakultas Pertanian \\ ${ }^{4}$ Laboratorium Lapangan Peternakan, Program Studi Peternakan, Fakultas Pertanian \\ Universitas Syiah Kuala, Darussalam Aceh 23111 \\ Kopelma Darussalam, Syiah Kuala, Kota Banda Aceh, Aceh 24411 \\ allaily@unsyiah.ac.id
}

\begin{abstract}
Rising duck intensively fed commercial feed requires high production costs. Processing of local feed raw materials available in the environment to be a high feed quality in order to reduce the cost. The purpose of this research was to utilize the resources of local feed ingredients using anaerobic fermentation process. The ration was based on nutritional needs of broiler ducks with $19 \%$ crude protein and metabolizable energy $3.100 \mathrm{kcal} / \mathrm{kg}$. Water containing lactic acid bacteria (LAB) $105 \mathrm{cfu} / \mathrm{g}$ was added to ration until water content of $45 \%$. Then ration put into airtight storage containers (silos), compacted and sealed. The experiment using a completely randomized design with 4 treatments fermentation time namely $\mathrm{T} 0=0$ days, $\mathrm{T} 1=3$ days, $\mathrm{T} 2=6$ days and $\mathrm{T} 3=$ 9 days. Each treatment was repeated three times. The physical quality in three days fermentation time to produce color, smell and texture was the best. Fermentation time was significantly to increases the water content, decrease $\mathrm{pH}$ value, but not significant to reduce dry matter content. Biological quality showed that fermentation 0-9 days no mold growth and $100 \%$ success rate. In conclusion that minimum of three days fermentation potential to be used as ducks feed system.
\end{abstract}

Key Words: Anaerobic Fermentation, Ducks, Fermentation Time, Local Feed Ingredients, Lactic Acid Bacteria

\begin{abstract}
ABSTRAK
Pemeliharaan itik secara intensif menggunakan pakan komersial membutuhkan biaya produksi yang tinggi. Pengolahan bahan baku pakan yang tersedia di lingkungan sekitar menjadi pakan yang berkualitas menjadi salah satu cara untuk menekan biaya tersebut. Tujuan dari penelitian ini adalah memanfaatkan sumber daya bahan baku pakan lokal dengan menggunakan proses fermentasi anaerob. Ransum disusun berdasarkan nutrisi kebutuhan itik pedaging dengan protein kasar $19 \%$ dan energi metabolis $3.100 \mathrm{kkal} / \mathrm{kg}$. Ransum dicampur bakteri asam laktat (BAL) $105 \mathrm{cfu} / \mathrm{gram}$ sampai kandungan air 45\%, dimasukkan ke dalam wadah penyimpanan yang kedap udara (silo), dipadatkan dan ditutup rapat. Penelitian ini menggunakan rancangan acak lengkap (RAL) dengan 4 perlakuan waktu fermentasi yaitu $\mathrm{T} 0=0$ hari, $\mathrm{T} 1=3$ hari, $\mathrm{T} 2=6$ hari dan $\mathrm{T} 3=9$ hari. Perlakuan waktu nyata meningkatkan kadar air, menurunkan nilai $\mathrm{pH}$, namun tidak nyata menurunkan kandungan bahan kering. Hasil penelitian menunjukkan kualitas fisik pakan fermentasi dengan waktu tiga hari menghasilkan warna, bau dan tekstur terbaik. Waktu fermentasi selama sembilan hari tidak memperlihatkan pertumbuhan jamur dan tingkat keberhasilan 100\% sehingga secara biologi pakan fermentasi baik. Disimpulkan bahwa waktu fermentasi minimal tiga hari memiliki potensi yang baik sebagai cara pengolahan pakan itik.
\end{abstract}

Kata Kunci: Pakan Lokal, Bakteri Asam Laktat, Fermentasi Anaerob, Itik, Waktu Fermentasi 


\section{PENDAHULUAN}

Biaya produksi tertinggi pada peternakan unggas, terutama itik dapat mencapai hingga $80 \%$ dari biaya pakan. Hal ini disebabkan karena peternakan intensif menggunakan pakan komersil yang mahal harganya. Oleh karena itu alternatif pakan untuk menekan biaya pakan adalah dengan mengoptimalkan penggunaan bahan pakan lokal yang mudah didapat dan tersedia di sekitar tempat pemeliharaan. Potensi bahan lokal cukup banyak dalam segi jumlah sehingga dapat mengurangi biaya transportasi dan ketergantungan peternak terhadap impor. Beberapa bahan lokal yang tersedia yaitu sagu, ampas kelapa dari hasil samping dari industri kelapa yang memiliki nilai protein $4,12 \%$, serat kasar $37,1 \%$ dan kadar air 0,33\% (Yulvianti et al. 2015), tepung daun lamtoro, dedak padi, bungkil kelapa, limbah ikan campur, jagung kuning lokal, bekicot dan minyak kelapa. Bahan baku seperti kelapa tersedia 15,5 milyar butir per tahun (BLP 2016). Hasil samping pengolahan kelapa dapat dijadikan sumber bahan pakan. Namun kuantitas bahan baku lokal tidak diiringi oleh kualitas yang selalu baik dan konsisten, sehingga perlu penanganan dengan teknologi pengolahan pakan.

Teknologi fermentasi anaerob dapat digunakan untuk mempertahankan kualitas nutrisi dan menekan biaya produksi. Fermentasi anaerob adalah proses yang melibatkan bakteri asam laktat (BAL) untuk dapat mempertahankan produk pakan sekaligus memperkaya manfaat pakan dengan manfaat biotik yang ada dan produk asam laktat sebagai hasil utamanya. Akibat proses fermentasi, maka pakan memiliki pH asam. Kondisi asam ini dapat mencegah biota patogen sehingga daya simpan pakan akan menjadi panjang.

Proses fermentasi dapat mempertahankan nutrien pada saat penyimpanan. Keadaan ini dapat menyediakan pakan pada saat sumber pakan tidak ada, dan mengawetkan pakan pada saat sumber pakan melimpah. Kondisi sumber pakan yang tinggi kadar air akan mempercepat proses fermentasi, sehingga pemanfaatan bahan pakan dapat digunakan tanpa melewati proses pengeringan terlebih dahulu. Allaily (2006) menyatakan bahwa pakan fermentasi dengan kadar air 50\% mampu memiliki kualitas terbaik dari sisi konversi pakan itik pedaging. Pemberian pakan fermentasi hingga 55\% dapat memperbaiki konversi itik lokal Vietnam (Lien et al. 2005).

Pakan fermentasi dapat memperbaiki performa ternak (Missotten et al. 2013; Ahmed et al. 2014; Ridla et al. 2014), profil darah (Fazhi et al. 2011), kualitas daging (Ahmed et al. 2014; Sutama et al. 2015), amonia feses (Ahmed et al. 2014), namun potensinya sebagai pakan unggas seperti itik belum banyak dilaporkan dibandingkan penggunaannya pada ternak ruminansia (Abd-Hady et al. 2012). Penelitian ini bertujuan untuk menguji sumber daya bahan baku pakan lokal menggunakan proses fermentasi anaerob dengan perlakuan perbedaan waktu fermentasi terhadap kualitas fisik, kimia dan biologi.

\section{MATERI DAN METODE}

Materi yang digunakan dalam penelitian ini terdiri dari bahan pakan lokal yang terdiri dari sagu, ampas kelapa, tepung daun lamtoro, dedak padi, bungkil kelapa, limbah ikan campur, jagung kuning, keong mas, minyak kelapa dan larutan BAL yaitu efektif mikroorganisme (EM4). Peralatan yang digunakan yaitu botol kaca wadah fermentasi, isolasi, $\mathrm{pH}$ meter dan timbangan.

\section{Cara pembuatan pakan fermentasi anaerob}

Bahan-bahan kering dihaluskan dengan menggunakan hammer mill dan bahan-bahan yang segar dihaluskan dengan menggunakan blender. Keong mas direbus terlebih dahulu 
sebelum dihaluskan. Bahan-bahan yang sudah halus diaduk hingga homogen dengan komposisi sesuai Tabel 1 dan ditambahkan air hingga berkadar air 45\%. Air yang ditambahkan telah mengandung BAL $10^{5} \mathrm{cc} / 1$ liter air. Penambahan air dapat dilakukan dengan menggunakan rumus sebagai berikut:

Silase berkadar air $(\mathrm{kg})=\frac{\text { BK ransum }(96)}{\text { BK silase yang ingin dibuat }(96)} \times$ jumlah ransum komplit $(\mathrm{kg})$

Air yang ditambahkan $(\mathrm{ml})=$ Silase berkadar air $(\mathrm{kg})-$ jumlah ransum komplit $(\mathrm{kg})$

Selanjutnya setelah ransum homogen, dimasukkan ke dalam botol yang telah disterilkan, dipadatkan dan ditutup agar kondisi anaerob. Botol yang telah ditutup disimpan untuk difermentasi pada suhu kamar. Lamanya waktu fermentasi yaitu 0, 3, 6 dan 9 hari.

Tabel 1. Komposisi ransum penelitian dan kandungan nutrien

\begin{tabular}{lc}
\hline \hline Bahan pakan & Komposisi (\%) \\
\hline Sagu & 15 \\
Ampas kelapa & 14 \\
Daun lamtoro & 10 \\
Dedak padi & 30 \\
Bungkil kelapa & 13 \\
Limbah ikan lokal & 8 \\
Keong mas & 10 \\
\hline Jumlah & 100 \\
\hline Zat nutrien & \\
Protein $(\%)$ & 19 \\
EM (kkal/kg) & 3.029 \\
Serat kasar $(\%)$ & 9,67 \\
Lemak $(\%)$ & 8,40 \\
Ca $(\%)$ & 0,83 \\
P $(\%)$ & 0,83 \\
\hline
\end{tabular}

Sumber: Laboratorium Nutrisi Ternak, Program Studi Peternakan, Fakultas Pertanian, Unsyiah

\section{Parameter yang diamati}

Parameter yang diamati adalah: (1) Kualitas fisik: warna, bau dan tekstur; (2) Kualitas kimia yaitu kadar air, bahan kering, dan $\mathrm{pH}$; (3) Kualitas biologi: skor jamur dan persentase keberhasilan fermentasi. Nilai kriteria yang digunakan berdasar Soekanto et al. (1980) sebagai berikut: (1) Jamur, skor 1-3 (3 tidak berjamur, 2 berjamur di atas $10 \%$ dan 1 berjamur 75\%); (2) Warna, skor 1-3 (3 kuning kecokelatan, 2 kuning kehitaman dan 1 hitam); (3) Bau, skor 1-3 (3 asam, 2 tidak asam tidak busuk dan 1 busuk); dan (4) Tekstur, skor 1-3 (3 berbutir, 2 agak berbutir dan 1 lembut). 


\section{Rancangan penelitian}

Penelitian ini menggunakan Rancangan Acak Lengkap (RAL) yang terdiri dari 4 perlakuan waktu penyimpanan yaitu $\mathrm{T} 0=0$ hari, $\mathrm{T} 1=3$ hari, $\mathrm{R} 2=6$ hari dan $\mathrm{R} 3=9$ hari, masing-masing perlakuan ada 3 ulangan. Data dianalisis ragam analysis of variance (ANOVA) (Steel \& Torrie 1995).

\section{HASIL DAN PEMBAHASAN}

\section{Kualitas fisik}

Kualitas fisik ransum komplit yang difermentasi disajikan pada Tabel 2. Warna, bau, dan tekstur ransum komplit T1 dengan waktu fermentasi 3 hari menunjukkan nilai rataan tertinggi dibandingkan nilai dari perlakuan lainnya kecuali kontrol. Waktu fermentasi 3 hari mampu mempertahankan warna T1 sama seperti sebelum dilakukan fermentasi. Menurut Soekanto et al. (1980) nilai 3 yaitu kuning kecoklatan mendekati warna asalnya adalah bahwa pakan fermentasi masih dalam keadaan baik. Bau pada T1 telah menurun dari angka 3 ke angka 2,8. Hal ini mengindikasikan bahwa proses fermentasi secara fisik telah berhasil memberikan bau asam. Tekstur pada T1 telah menurun dibandingkan kontrol. Sedangkan nilai T2 dan T3 berada di bawah nilai T1, dengan demikian T1 terbaik dibandingkan perlakuan lainnya.

Tabel 2. Rata-rata nilai skor fisik ransum komplit fermentasi

\begin{tabular}{lcccc}
\hline \hline \multirow{2}{*}{ Parameter } & \multicolumn{5}{c}{ Lama fermentasi (hari) } \\
\cline { 2 - 5 } & T0 & T1 & T2 & T3 \\
\hline Warna & 3,0 & 3,0 & 2,6 & 2,6 \\
Bau & 3,0 & 2,8 & 2,6 & 2,4 \\
Tekstur & 3,0 & 2,6 & 2,4 & 2,2 \\
\hline
\end{tabular}

Falola et al. (2013) menyatakan bahwa warna ransum fermentasi yang baik adalah ransum yang warnanya mendekati warna sebelum difermentasi. Menurut McDonald et al. (1991) kualitas fermentasi sangat tergantung dari suhu, pH serta kadar air. Hidayat (2014) menyatakan bahwa warna rumput Raja yang difermentasi dengan kondisi suhu yang tidak tinggi menyebabkan kadar karoten tidak berubah sehingga waktu fermentasi 28 hari masih menyerupai warna bahan asalnya. Hasil penelitian ini menunjukkan 3 hari waktu fermentasi mampu mempertahankan warna asal bahan. Nilai mendekati angka 3 baik pada warna, bau, dan tekstur menunjukkan bahwa pakan fermentasi dalam keadaan baik.

Kurnianingtyas et al. (2012) menambahkan aditif pada fermentasi rumput Kolonjono menghasilkan nilai rataan lebih tinggi yaitu 3 dibandingkan dengan kontrol 2,1. Namun demikian, aditif molases akan memacu proses oksidasi sehingga meningkatkan suhu fermentasi yang menyebabkan warna menjadi lebih buruk. Hasil penelitian yang berbeda dinyatakan oleh Kojo et al. (2015) bahwa penambahan aditif dedak padi dan jagung pada fermentasi sebesar 8 dan $12 \%$ belum berpengaruh terhadap warna dan bau, tetapi berpengaruh baik terhadap tekstur. Herlinae et al. (2015) menyatakan bahwa penggunaan aditif EM4 dan gula merah mampu memberikan pengaruh yang baik terhadap bau, rasa, warna dan tekstur. Tekstur yang baik adalah masih jelas seperti bahan alaminya. 


\section{Kualitas kimia}

Rataan nilai kualitas kimia ransum komplit fermentasi anaerob dapat dilihat pada Tabel 3. Waktu fermentasi sangat nyata $(\mathrm{P}<0,01)$ meningkatkan kadar air dan menurunkan $\mathrm{pH}$, namun tidak nyata pengaruhnya terhadap penurunan bahan kering.

Tabel 3. Rata-rata nilai kualitas kimia ransum komplit fermentasi

\begin{tabular}{lcccc}
\hline \multirow{2}{*}{ Parameter } & \multicolumn{4}{c}{ Lama fermentasi (hari) } \\
\cline { 2 - 5 } & 0 & 3 & 6 & 9 \\
\hline Kadar air & $71,77^{\mathrm{a}}$ & $72,49^{\mathrm{ab}}$ & $73,22^{\mathrm{bc}}$ & $73,59^{\mathrm{c}}$ \\
Bahan kering & 28,23 & 27,51 & 26,78 & 26,41 \\
$\mathrm{pH}$ & $5,85^{\mathrm{c}}$ & $4,93^{\mathrm{a}}$ & $5,00^{\mathrm{b}}$ & $5,01^{\mathrm{b}}$ \\
\hline
\end{tabular}

Huruf dalam baris yang sama dengan superskrip berbeda menunjukkan perbedaan yang sangat nyata $(\mathrm{P}<0,01)$. Laboratorium Nutrisi Ternak, Prodi Peternakan, Fakultas Pertanian, Unsyiah

Sumber: Miswar (2012) dan Rianah (2013)

McDonald et al. (1991) menuliskan bahwa $\mathrm{pH}$ yang baik untuk pakan fermentasi bahan hijauan adalah 4, sedangkan bahan sereal adalah 4,6. Keadaan $\mathrm{pH}$ yang baik akan menghambat mikroba yang patogen. Penghambatan mikroba patogen ini tergantung pada suhu, pH serta kadar air. Kadar bahan kering $20 \%$ pada bahan dapat mempertahankan $\mathrm{pH}$ bernilai 4 pada hasil fermentasi.

Menurut Allaily et al. (2011) ransum dengan kadar air 50\% dengan waktu fermentasi 1 minggu menghasilkan nilai pH 4,2 (Gambar 1). Hasil tersebut bila dibandingkan dengan penelitian ini, yaitu pH hanya mencapai 4,9 pada hari ketiga (Tabel 3). Hal ini disebabkan karena perbedaan bahan yang digunakan serta kandungan kadar air ransum. Penelitian Allaily et al. (2011) menggunakan umbi (cassava) dan daun yang tinggi karbohidrat terlarut sebagai makanan bakteri asam laktat yang mudah dicerna sehingga cepat memproduksi suasana asam. Menurut McDonald et al. (1991) lambatnya laju penurunan $\mathrm{pH}$ akan berakibat baik bagi proses proteolisis pada saat fermentasi. Hal ini berdampak baik bagi nutrien yang terkandung dalam ransum.

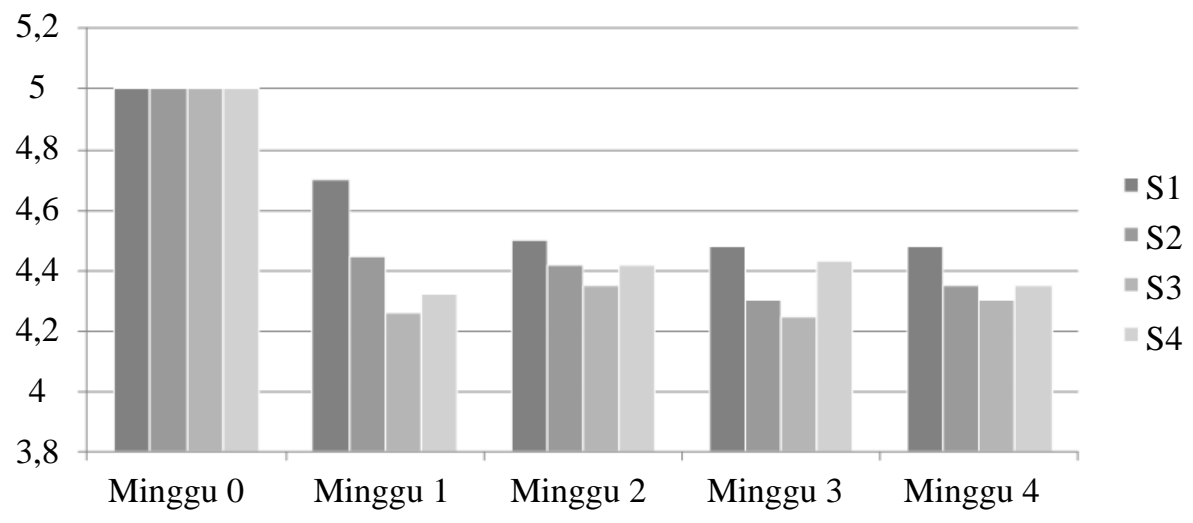

Gambar 1. pH silase dengan kadar air dan waktu penyimpanan berbeda

Sumber: Allaily et al. (2011)

McDonald et al. (1991) menyatakan bahwa apabila bahan kering tinggi, maka proteolisis akan terhambat, keadaan suhu akan bergerak linier dengan proses proteolisis, walaupun demikian hal ini tidak selalu konsisten. Ma et al. (2006) menyatakan bahwa 
kadar air bahan akan membantu proses fermentasi. Kadar air akan membantu BAL melakukan proses fermentasi. Penambahan inokulasi pada proses fermentasi juga dapat mempercepat turunnya pH (Muck 2013). Penambahan waktu fermentasi juga dapat meningkatkan nilai pH (Setapar et al. 2012). Nilai pH serta kandungan BAL dari pakan fermentasi basah akan memperbaiki mikrobia saluran pencernaan sehingga akan memperbaiki imunitas (Hasan et al. 2016). Imunitas yang baik berdampak baik bagi kesehatan itik yang mengkonsumsi pakan fermentasi (Allaily et al. 2017).

\section{Kualitas biologi}

Nilai biologi dapat dilihat dengan mengamati tumbuhnya jamur pada saat proses fermentasi anaerob disajikan pada Tabel 4. Waktu fermentasi tidak nyata $(\mathrm{P}>0.05)$ terhadap pertumbuhan jamur dan persentase keberhasilan fermentasi. Menurut Soekanto et al. (1980) nilai rataan skor jamur 3 artinya tidak ditemukan jamur sama sekali dan keberhasilan fermentasi menunjukkan nilai persentase maksimal $100 \%$. Hal ini membuktikan bahwa proses fermentasi cepat mencapai kondisi anaerob, sehingga jamur yang hidup pada kondisi aerob tidak dapat tumbuh.

Tabel 4. Rata-rata nilai skor jamur dan keberhasilan fermentasi

\begin{tabular}{lcccc}
\hline \hline \multirow{2}{*}{ Parameter } & \multicolumn{5}{c}{ Lama fermentasi (hari) } \\
\cline { 2 - 5 } & 0 & 3 & 6 & 9 \\
\hline Jamur & 3 & 3 & 3 & 3 \\
Keberhasilan fermentasi (\%) & 100 & 100 & 100 & 100 \\
\hline
\end{tabular}

Kondisi anaerob yang cepat tercapai disebabkan oleh penambahan zat aditif EM 4 serta kondisi wadah anaerob. Herlinae et al. (2015) menyatakan bahwa penambahan EM4 pada proses fermentasi rumput Gajah dapat memperbaiki karakteristik bau, warna, rasa dan tekstur. Proses dan hasil ransum komplit fermentasi dapat dilihat pada Gambar 2.

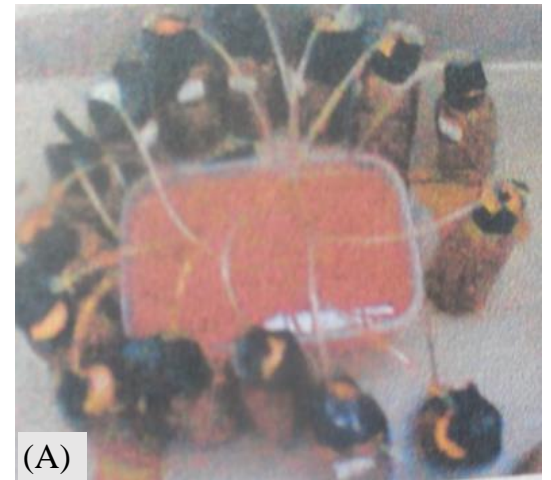

A: Botol kaca wadah fermentasi

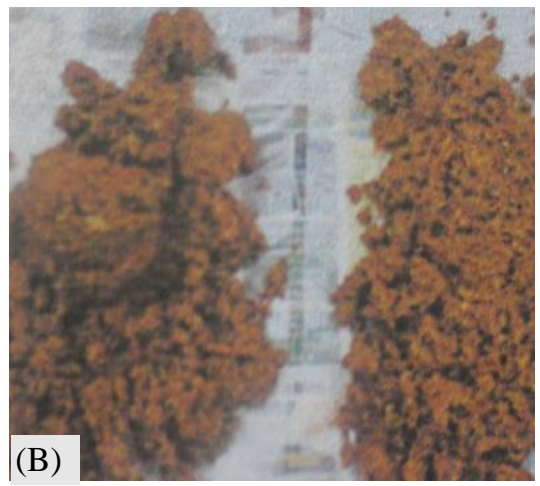

B: Ransum komplit hasil fermentasi

Gambar 2. Proses dan hasil ransum komplit fermentasi

McDonald et al. (1991) melaporkan bahwa setelah keadaan anaerob pada saat fermentasi awal, mikroorganisme yang dapat tumbuh adalah bakteri asam laktat, enterobakteri, klostridia dan beberapa basillus, serta ragi berkompetisi untuk mendapatkan nutrisi yang tersedia. Mikroba aerob akan segera terhambat dan tidak bertahan hidup saat pH asam. Pemberian aditif berupa mikroba EM4 (Herlinae et al. 2015), aditif dedak padi dan jagung (Kojo et al. 2015), serta molases (Kurnianingtyas et al. 2012) adalah beberapa cara agar proses fermentasi cepat mencapai kondisi asam, sehingga nilai nutrien ransum terawetkan. 
Kondisi bahan baku yang dipakai juga memegang peranan penting dalam proses keberhasilan fermentasi. Seperti bahan pakan berupa keong mas melewati proses perebusan sebelum difermentasi, sehingga mikroba patogen dapat diminimalisir pada bahan (Gambar 3). Hal ini akan meminimalkan bakteri patogen dalam proses fermentasi. Penambahan aditif seperti cairan molases sebagai sumber energi bakteri anaerob akan memperkecil pertumbuhan jamur dan meningkatkan kesempatan keberhasilan fermentasi (Hidayat 2014).

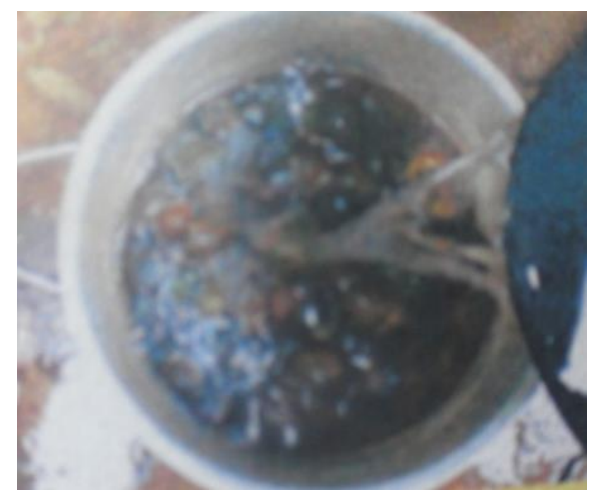

Gambar 3. Proses perebusan keong mas

\section{KESIMPULAN}

Pakan fermentasi anaerob yang menggunakan bahan pakan lokal dengan waktu fermentasi minimal tiga hari baik dari kualitas fisik, kimia, dan biologi, memiliki potensi yang baik untuk dapat dijadikan pakan itik.

\section{DAFTAR PUSTAKA}

Allaily. 2006. Kajian silase ransum komplit berbahan baku pakan lokal pada itik Mojosari Alabio jantan [Tesis]. [Bogor (Indonesia)]: Institut Pertanian Bogor.

Allaily T, Nahrowi R, Ridla M, Yaman MA, Setiyono A. 2017. Effects of organic acids on Salmonella enteritidis growth inhibition and ileum surface area in laying ducks fed anaerobically fermented feed. Int J Poult Sci. 16:98-104.

Allaily, Nahrowi R, Ridwan R. 2011. Kajian silase ransum komplit berbahan baku pakan lokal pada itik Mojosari Alabio jantan. Agripet. 11:35-40.

Abd-Hady MAA, Gabr AA, El-Ayouty SA, Shahin MAZ. 2012. Effect of physical and chemical treatments on Berseem silage quality, nutritive values, rumen fermentation and blood metabolites of rams. Anim Poult Prod. 3:267-288.

Ahmed ST, Mun HS, Islam, MM, Yang CJ. 2014. Effects of fermented corni fructus and fermented kelp on growth performance, meat quality, and emission of ammonia and hydrogen sulphide from broiler chicken droppings. Br Poult Sci. 55:745-51.

Falola OO, Alasa MC, Babayemi OJ. 2013. Assessment of silage quality and forage acceptability of vetiver grass (Chrysopogon zizanioides L Roberty) ensiled with cassava peels by wad goat. Pakistan J Nut. 12:529-533.

Fazhi X, Lvmu L, Jiaping X, Kun Q, Zhide Z, Zhangyi L. 2011. Effects of fermented rapeseed meal on growth performance and serum parameters in ducks. Asian-Aust J Anim Sci. 24:678684.

Herlinae, Yemima, Rumiasih. 2015. Pengaruh aditif EM4 dan gula merah terhadap karakteristik silase rumput Gajah (Pennisetum purpureum). J Ilmu Hewan Tropika. 4:27-30. 
Kojo RM, Rustandi, Tulung YRL, Malalantang SS. 2015. Pengeruh penambahan dedak padi dan tepung jagung terhadap kualitas fisik silase rumput Gajah. J Zootek. 35:21-29.

Kurnianingtyas IB, Pandansari PR, Astuti I, Widyawati SD, Suprayogi WPS. 2012. Pengaruh macam akselerator terhadap kualitas fisik, kimiawi dan biologis silase rumput Kolonjono. Trop Anim Husb. 1:7-14.

Lien LV, Thoa PT, Thai NV, Tao NH. 2005. Use of Lactobacillus plantarum inoculate to improve the fermentation process of shrimp by products silage and evaluation of the silage as a protein source for duck [Internet]. [cited 6 June 2006]. Available from: www.mekarn.org

Hasan SAJ, Lokman IH, Saad AN, Zuki ABZ, Kassim AB. 2016. Research article effects of dietary supplementation of wet fermented feed with probiotic on the production performance of Akar Putra chicken. Asian J Poult Sci. 10:72-77.

Hidayat N. 2014. Karakteristik dan kualitas silase rumput Raja menggunakan berbagai sumber dan tingkat penambahan karbohidrat fermentable. Agripet. 14:42-49.

Ma BL, Subedi KD, Stewart DW, Dwyer LM. 2006. Dry matter accumulation and silage moisture changes after silking in leafy and dual purpose corn hybrids. Am Soc Agron. 98:922-929.

McDonald P, Henderson AR. dan Heron SJE. 1991. The biochemistry of silage. 2n Ed. English (UK): Chalcombe Publication.

Missotten JA, Michiels J, Dierick N, Ovyn A, Akbarian A, De Smet S. 2013. Effect of fermented moist feed on performance, gut bacteria and gut histo-morphology in broilers. Br Poult Sci. 54:627-34.

Muck RE. 2013. Recent advance in silage microbiology. Agric Food Sci. 22:3-15.

Ridla M, Allaily FK, Nikmah, Ramli N. 2014. Performance of Mojosari Alabio males ducks fed complete ration silage. Anim Prod. 16:176-182.

Setapar SHM, Talibb NA, Azizb R. 2012. Review on crucial parameters of silage quality. Chem Biol Environ Eng Soc Proc. 3:99-103.

Soekanto L, Subur P, Soegoro M, Riastianto U, Muridan, Soedjadi, Soewondo R, Toha M, Soediyo, Purwo S, Musringan, Sahari M, Astuti. 1980. Laporan proyek konservasi hijauan makanan ternak Jawa Tengah. Jakarta (Indonesia): Direktorat Bina Produksi, Direktorat Jenderal Peternakan, Departemen Pertanian dan Fakultas Peternakan, Universitas Gadjah Mada.

Steel RGD, Torrie JH. 1995. Prinsip dan prosedur statistika. Jakarta (Indonesia): PT Gramedia Pustaka Utama.

Sutama INS, Mudita IM, Suberata IW, Siti NW. 2015. Effect of dietary biosupplement fermented earthworm microbes consortium inoculant on the carcass production and cholesterol blood profile of Baliness duck. Agric Anim Sci.8:1-6.

Yulvianti M, Ernayati W, Tarsono T, Alfian MR.2015. Pemanfaatan ampas kelapa sebagai bahan baku tepung kelapa tinggi serta dengan metode freeze drying. J Integrasi Proses. 5:101-107. 